DOI: https://doi.org/10.46502/issn.1856-7576/2021.15.03.10

\title{
Research of social expectations of university students in the dimensions of psychological well-being
}

\section{Investigación de las expectativas sociales de los estudiantes universitarios en dimensiones del bienestar psicológico}

\author{
Oleksandr Semenov \\ o_semen@yahoo.com \\ https://orcid.org/0000-0002-3839-4725
}

Doctor of Pedagogical Sciences, Full Professor of the Department of General Pedagogy and Preschool Education, Volyn National University named after Lesia Ukrainka, Lutsk,

Ukraine.

Petro Oleshko

oleshko.ippo@gmail.com

https://orcid.org/0000-0002-9599-6052

Candidate of Historical Sciences, Director of the Volyn Institute of Postgraduate

Pedagogical Education, Lutsk, Ukraine.

Svitlana Tsymbal

tsymbal_s.v@nubip.edu.ua

https://orcid.org/0000-0003-0652-369X

Doctor of Psychological Sciences, Associate Professor of the Department of English for Technical and Agrobiological Specialities, National University of Life and Environmental Sciences of Ukraine, Kyiv, Ukraine.

Vera Liashko

vvlyashko@gmail.com

https://orcid.org/0000-0003-3717-7240

Candidate of Psychological Sciences, Associate Professor of the Department of Special Education, Kherson State University, Kherson, Ukraine.

\section{Alyona Shevchenko}

kalanchak27@gmail.com

https://orcid.org/0000-0002-6581-6938

Bachelor of Psychology, Department of Psychology, Kherson State University, Kherson,

$$
\text { Ukraine. }
$$

Ihor Popovych

ihorpopovych999@gmail.com

https://orcid.org/0000-0002-1663-111X

Doctor of Psychological Sciences, Full Professor of the Department of Psychology, Kherson State University, Kherson, Ukraine.

Recibido: $26 / 08 / 21$

Aceptado: 20/10/21 


\section{Abstract}

The aim of the article is to argue theoretically and empirically study the relationship between social expectations and psychological well-being of university students. Methodological starting points of empirical research are outlined. Valid and reliable test methods are used to study the psychological content parameters of social expectations and psychological well-being. The results determined that the psychological features of social expectations and psychological well-being of student's youth are theoretically substantiated. It was found that the respondents have an average level of parameters of psychological well-being and social expectations, which indicates moderate life satisfaction and the presence of adequate orientation in the socio-psychological reality. The most formed components of psychological well-being are the balance of affect and meaningfulness, which indicates the awareness of their own lives by student's youth. It is recorded that the respondents have the least formed - self-acceptance, positive attitude and autonomy.

Key words: hope, institution of higher education, subjective well-being, autonomy, life satisfaction.

\section{Resumen}

El objetivo del artículo es argumentar teóricamente y estudiar empíricamente la relación entre las expectativas sociales y el bienestar psicológico de estudiantes universitarios. Se describen los puntos de partida metodológicos de la investigación empírica. Se utilizan métodos de prueba válidos y fiables para estudiar los parámetros de contenido psicológico de las expectativas sociales y el bienestar psicológico. Los resultados determinaron que las características psicológicas de las expectativas sociales y el bienestar psicológico de la juventud del estudiante están fundamentadas teóricamente. Se encontró que los encuestados tienen un nivel promedio de parámetros de bienestar psicológico y expectativas sociales, lo que indica una satisfacción vital moderada y la presencia de una adecuada orientación en la realidad socio-psicológica. Los componentes más formados del bienestar psicológico son el equilibrio del afecto y la significación, lo que indica la conciencia de sus propias vidas por parte de los jóvenes de los estudiantes. Se registra que los encuestados son los menos formados: autoaceptación, actitud positiva y autonomía.

Palabras clave: esperanza, institución de educación superior, bienestar subjetivo, autonomía, satisfacción con la vida.

\section{Introduction}

In recent years, society has undergone many changes: social, economic, natural, political and epidemiological. Any transformation of the world affects the personality of each man, thereby changing the man himself. (Arbeláez-Campillo et al., 2020). 
During the progression of the global pandemic COVID-19, the individual adapts to changes in modern realities by modifying their own social expectations of the near future to adequately perceive psychological reality and function effectively in society (Khmiliar et al., 2020). Individual expectations are regulatory in nature, i. e. they affect human behavior, its relationship with the environment and society in general (Popovych et al., 2021b).

Important for positive functioning in the socio-psychological space is the psychological well-being of the individual, which is an indicator of mental health. According to the World Health Organization, mental health is a state of well-being in which everyone can realize their own potential, cope with life's stresses, work productively and productively, and contribute to the life of their community. Psychological well-being is a multicomponent phenomenon, which is influenced by various factors that reduce or increase its level, thereby affecting the general condition of the individual.

A special age group that is sensitive to any changes in the surrounding reality is the student youth, because during this period there is a formation of stable personality structures, which can still be exposed to certain influences. It is important to know about the psychological well-being and social expectations of young people, because they are the variable that will affect the future. Therefore, the study of the psychological well-being and social expectations of student's youth, even during the progression of the COVID-19 pandemic, is extremely relevant and significant in the global dimension.

Psychological science distinguishes a number of approaches for understanding the concept of "psychological well-being", including: hedonistic and eudemonic, integrative and an approach that considers psychological well-being within the concept of mental health. However, it should be noted that there is no generally accepted definition of "psychological well-being".

I. Hedonistic approach, which is based on the idea of achieving satisfaction and avoiding dissatisfaction, the balance between positive and negative effects.

II. The eudemonic approach considers psychological well-being as self-realization and individualization of the person, and also aspiration of the person to full realization of own potential which is traced in positive functioning of the person in all spheres of life.

III. The integration approach combines hedonistic and eudemonistic approaches and interprets psychological well-being as a multidimensional phenomenon that includes in its structure life satisfaction, positive affect, realization of one's own potential.

IV. Psychophysiological approach, in which psychological well-being acts as an element of psychological health of the individual and aims to fully preserve the psychophysiological functions of man.

The structure of psychological well-being is multicomponent and is represented by the following components: emotional component is responsible for the reaction and 
perception of their own emotions in relation to themselves and the environment, behavioral component is realized in actions, deeds and manifests itself in regulation behavior, the cognitive component is traced in the assessment and understanding of situations and volitional - the management of actions and decisions (Ma et al., 2020). The structure also includes the value component, which is responsible for the value orientations of the individual in relation to life and the motivational component, which affects human life.

Psychological well-being is defined (Shiryaeva, 2008) as a set of necessary personal resources that ensures the subjective and objective success of the individual in the system of "subject-space". The following five components are defined as components of psychological well-being: affective (balance of positive and negative affective experiences); component related to meta-needs (personal growth, measure of selfrealization); worldview (presence of goals in life); intrareflexive (self-acceptance); interreflexive (competence in relations with the environment) (Shiryaeva, 2008).

The functioning of the individual takes place in the social space, which is why a person is included in a diverse outline of expected and unexpected events (Shevchenko, 2019). An element of expectation can be any object of the surrounding reality, subject, object, event, etc. The structure of expectations has three components: cognitive - knowledge of the element, phenomenon, person to whom expectations are directed, affective - attitude and assessment of the object / subject of expectations and behavioral component responsible for actions, actions in relation to subject of expectations (Popovych et al., 2020b; 2020c). For adequate orientation in psychological reality, a person must learn certain rules, norms, values of society, so that they become certain internal regulators, which he can rely on in predicting the near future. It is social expectations that play this role.

Social expectations, like any psychological phenomenon, perform a number of functions: regulatory, mediation, corrective, orientation, prognostic, evaluative, stabilization, transformational, control (Popovych et al., 2021c). Each of these functions helps an individual to construct, implement their own predictions according to certain elements of reality.

Social expectations are a temporal phenomenon aimed at the future, because constructing and placing expectations on results in the past is absurd, the main essence of this phenomenon is forecasting, which is why social expectations help to construct the future, based on certain knowledge, facts of the present, to build certain plans, goals, choosing the strategy of behavior that will achieve the desired result.

Social expectations acquire the status of objective subjectivity, due to radical changes and conditions of variability. Having autonomy and freedom of behavior in the space of individual social and behavioral actions, social self-esteem, choice of life trajectories, the individual aligns his behavior with the expectations of loved ones and their own expectations of the social world (Popovych et al., 2020a; 2021a). Mental states of 
expectation are a kind of mental states that integrate mental processes and properties of the individual and regulate its activities.

By social expectations we mean prognostic expectations about the subject, object or a certain course of events in the possible future, which helps to navigate the sociopsychological reality, and are based on cognitive, emotional and behavioral elements and are regulators of social behavior. Structure, interdependence of factors of mental states of expectations and psychological well-being are important components of educational and professional activity of students. Establishing these relationships will help to better organize the educational space of higher education students.

\section{Hypothesis}

We believe that psychological structure and interdependence of factors of psychological well-being and social expectations of student's youth are important components of the organization of process of educational and profile preparation.

\section{The aim}

Investigate the psychological structure and interdependence of factors of psychological well-being and social expectations of university students.

\section{Methodology of research}

The methodological basis of the empirical study of social expectations of university students in the measurement of psychological well-being was relevant to the research problem scientific principles, paradigms and concepts. We were guided by starting points that interpret social expectations as subjective orientations of any participant in the university educational space in relation to how he evaluates and how he is evaluated by other participants in the interaction and to which, in connection with this, he expects behavior from others and others expect from him. Expectations and psychological wellbeing are complex psychological phenomena, the content of which depends on the level of respondents' development, individual psychological characteristics, self-esteem, demands, reflexivity, the formation of the image of Self and Self-concept (Popovych et al., 2021c).

When developing the methodology of empirical research, a number of tested empirical models are taken into account, which measure the semantic features of interpersonal interaction of participants in educational space (Blynova et al., 2020b; Halian et al., 2020) adaptation potential (Blynova et al., 2020a; 2020c; Villasmil Espinoza et al., 2021), semantic parameters of training (Griban et al., 2019; Shkola et al., 2019) and educational work (Tsymbal, 2017; 2019) are similar or relevant to our scientific problem (Nosov et al., 2020a; 2020b; Shevchenko et al., 2020; Zinchenko et al., 2019; 2020). These studies are relevant in the context of establishing patterns of social expectations of students in the measurement of psychological well-being. 


\section{Participants}

Students from Volyn National University named after Lesia Ukrainka (Lutsk, Ukraine), National University of Life and Environmental Sciences of Ukraine (Kyiv, Ukraine), Kherson State University (Kherson, Ukraine) took part in our empirical study. The sample consisted of 100 people. The mean age of the sample was 19.8 years (range 18-21 years). There were $62.0 \%$ girls and $38.0 \%$ boys in the sample.

\section{Organization of research}

Ascertainment stage was made during February-March 2021. Students from these higher education institutions, representing different faculties, were randomly selected. The general university sample is formed according to all the requirements for this kind of empirical research and proportionally represents all regions of Ukraine. The study was agreed with the University administration. Students were informed in advance and volunteered to participate in the study. The study was performed in compliance with all ethical principles.

\section{Procedures and instruments}

At the stage of selection of psychodiagnostic tools, the complexity of the phenomena of psychological well-being and social expectations is taken into account, methods with questions or statements that require agreement or disagreement are applied. Selected techniques relevantly reflect the psychological content parameters. At the initial stage, valid and reliable test psychodiagnostic tools were used.

The questionnaire "The scales of psychological well-being" was used (Ryff, 1989). The questionnaire is designed to determine the level of such a multicomponent construct as the psychological well-being of the individual, as well as its parameters. This questionnaire consists of 84 items and includes six main scales: "Positive Relations with Others", "Autonomy", "Environmental Mastery", "Self-Acceptance", "Personal Growth", "Purpose in Life" and three additional ones: "Balance of affect", "Meaningfulness of life", "Human as an open system" and the integrated indicator "Psychological well-being".

The next method is the test MLO (Meaning of life orientations), which is an adapted version of the Purpose-in-Life Test (PIL), (Leontyev, 2006). The MLO test reveals a general indicator of life consciousness, as well as five subscales that reflect three specific content orientations (goals in life, life saturation and satisfaction with self-realization) and two aspects of the locus of control - locus of self-control and locus of life control).

The "Life Satisfaction Index A" ("LSIA") questionnaire (Neugarten, 1961) is designed to determine the general psychological state of a person, the degree of his psychological comfort and socio-psychological adaptation. The test consists of twenty statements and five scales: "Interest in life", "Consistency in achieving life goals", "Consistency between 
set and actually achieved goals", "Positive assessment of their qualities" and "General mood background".

The "Level of Social Expectations" questionnaire ("LSE"), (Popovych, 2017) was used to determine the level of social expectations of an individual. The questionnaire contains fourteen statements and four scales: "Awareness of the expected course of events", "Attitude to the participants of interpersonal interaction", "Level of expected results of activity", "Level of social expectations".

\section{Statistical analysis}

The received empirical data were processed and the results were graphically presented with the help of computer programs "SPSS" v. 24.0. Significant correlations are established by the Pearson correlation coefficient ( $r$ ). Arithmetic mean value of parameters (M) and mean-square deviation (SD) were calculated. Differences between values of parameters at level $p \leq .05$ considered statistically significant.

\section{Results and discussion}

The set of studied parameters of social expectations in the dimensions of psychological well-being is relevant and methodologically sound. The choice of psychodiagnostic tools takes into account the output conceptual provisions of the phenomenon of psychological well-being and social expectations.

We present descriptive frequency characteristics of the semantic parameters of the arithmetic mean (M) and standard deviation (SD) in Tabl. 1.

Table 1.

Values of scales of semantic parameters according to research methods $(n=100)$

\begin{tabular}{lcl}
\hline Scale & M & SD \\
\hline \multicolumn{3}{l}{ "The scales of psychological well-being" } \\
\hline Positive Relations with Others & 58.28 & 9.66 \\
\hline Autonomy & 58.5 & 9.04 \\
\hline Environmental Mastery & 59.48 & 10.04 \\
\hline Self-Acceptance & 53.54 & 10.27 \\
\hline Personal Growth & 61.64 & 9.03 \\
\hline Purpose in Life & 59.7 & 9.26 \\
\hline Balance of affect & 100.71 & 14.53 \\
\hline Meaningfulness of life & 94.42 & 12.02 \\
\hline Human as an open system & 63.79 & 7.01 \\
\hline Psychological well-being & 351.21 & 50.16 \\
\hline & "Purpose-in-Life Test" \\
\hline Purpose in Life & 27.93 & 7.26 \\
\hline
\end{tabular}


Revista de Tecnología de Información y Comunicación en Educación • Volumen 15, ํㅜ 3. Septiembre-diciembre 2021

\begin{tabular}{|c|c|c|}
\hline The process of life & 26.93 & 6.04 \\
\hline The result of life & 22.42 & 4.5 \\
\hline Locus of control - Self. & 19.83 & 4.38 \\
\hline Locus of control - Life & 27.93 & 6.67 \\
\hline \multicolumn{3}{|c|}{ "Life Satisfaction Index A" } \\
\hline Interest in life & 4.67 & 1.99 \\
\hline Consistency in achieving life goals & 5.11 & 1.76 \\
\hline $\begin{array}{l}\text { The consistency between the goals set and } \\
\text { achieved }\end{array}$ & 4.36 & 2.02 \\
\hline Positive assessment of their qualities & 4.54 & 1.99 \\
\hline General mood background & 4.79 & 2.00 \\
\hline Life Satisfaction Index & 23.48 & 6.94 \\
\hline \multicolumn{3}{|c|}{ "LSE" } \\
\hline $\begin{array}{l}\text { "Awareness of the expected course of } \\
\text { events" }\end{array}$ & 22.0 & 3.4 \\
\hline $\begin{array}{l}\text { "Expected attitude towards the participants } \\
\text { of interpersonal interaction" }\end{array}$ & 19.0 & 2.12 \\
\hline "Level of expected results of activities" & 42.0 & 5.67 \\
\hline "Level of social expectations" & 78.0 & 9.54 \\
\hline
\end{tabular}

Note: $\mathrm{M}$ - arithmetic mean; SD - mean-square deviation.

In the sample of respondents, the most formed are several components of psychological well-being - the balance of affect $(M=100.71)$ and meaningfulness of life $(M=94.42)$. This may indicate the awareness of their own lives by student's youth, present and past are perceived by them meaningfully. However, there is a certain dissatisfaction with the circumstances of their own lives, but there is a desire for its content and emotional saturation. The least formed components are self-acceptance $(M=53.54)$, positive relations with others $(M=58.28)$ and autonomy $(M=58.5)$. The student sample is characterized by secrecy in social interaction with other participants in the sociopsychological reality, a certain lack of independence and to some extent depending on the opinions and influence of others. We can attribute this to the unstable situation in the world, to the progression of COVID-19 and the impact of self-isolation on the components of student well-being.

According to the method of "Life Satisfaction Index A" it is determined that the student's youth is characterized by consistency in achieving life goals $(M=5.11)$, which indicates determination, focus on achieving goals, but the consistency between set and achieved goals is the least pronounced $(M=4.36)$, which may indicate that young students are focused on achieving goals, but may not complete what has been started. The general index of life satisfaction is at the average level.

According to the method of "Purpose-in-Life Test" it was found that the most developed in student's youth is the goal indicator $(M=27.93)$, which indicates that student's youth have goals in the future, which give life meaningfulness and focus, as well as developed 
is the indicator Locus of control - life, which indicates the presence of beliefs that a person is given control over his life, free to make decisions and implement them. The least developed component is the Locus of Control-Self $(M=19.83)$, which may indicate disbelief in their own ability to control the events of their lives. That is, modern student's youth, having certain life plans and goals, knowing that they can control their lives, do not believe in themselves and in their own strength and ability to change something. That is, young people can make plans that will not be backed by personal responsibility for their implementation.

According to the levels of psychological well-being, groups of students with different levels of this phenomenon were distinguished: low level of psychological well-being is $29.0 \%$, medium level $56.0 \%$, high level $15.0 \%$. We also identified three groups of students that differ in the levels of social expectations - low $-19.0 \%$, medium $-55.0 \%$, high $-26.0 \%$. (Fig. 1)

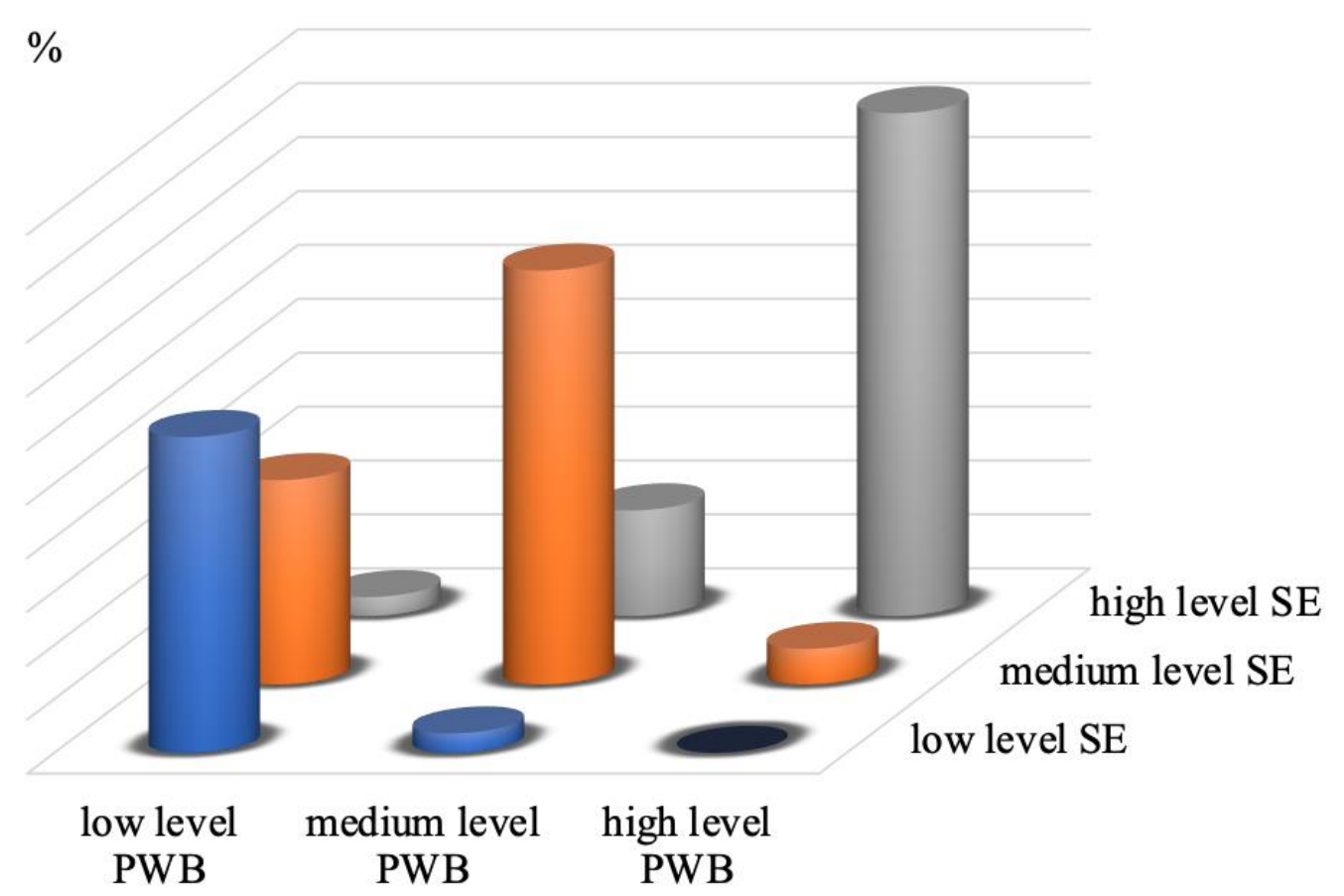

low level SE $\quad$ medium level SE $\quad$ high level SE

Note: PWB - psychological well-being, SE - social expectations

Figure 1. Groups of respondents with different levels of social expectations.

The logical conclusion is that a low level of psychological well-being corresponds to a low level of social expectations, an average level of psychological well-being corresponds to an average level of social expectations, a high level of psychological well-being corresponds to a high level of social expectations. It is established that the level of social expectations corresponds to the level of psychological well-being. 
Establishing correlations between indicators of low level of psychological well-being and social expectations of student's youth gave the following results: anticipating a certain course of events, a person builds certain plans-goals $(.571 ; p \leq .01)$, but they have unstable ideas about their implementation, mainly a person relies on his character traits and qualities $(.386 ; p \leq .05)$ and interest $(.397 ; p \leq .05)$; having life goals $(.451 ; p \leq .05)$ such a person transfers some responsibility to others and is not independent $(-.417 ; p \leq .05)$, because he does not believe in his own strengths and abilities (.402; $p \leq .05)$ and this will affect the general well-being $(.368 ; p \leq .05)$; trying to implement their plans, they try to construct a plan and consistently implement it $(.423 ; p \leq .05)$, but will not get pleasure (.413; $\mathrm{p} \leq .05)$.

Establishing correlations between the indicators of the average level of psychological well-being and social expectations of student's youth gave the following results: such individuals, setting certain goals, consistently achieve it $(.276 ; p \leq .05)$ and get pleasure and joy from it $(.364 ; p \leq .01)$. Unlike people with a low level of psychological well-being and social expectations, individuals with a medium level are independent and autonomous $(.357 ; p \leq .01)$, based on this there is personal growth $(.269 ; p \leq .05)$ and the level of psychological well-being $(.365 ; p \leq .01)$. Interaction with the outside world and people is easy and satisfying $(.354 ; p \leq .01)$, such a person knows his strengths $(.354$; $p \leq .01)$ and accepts his shortcomings (.442; $p \leq .01)$.

Realizing his life goals $(.298 ; p \leq .05)$ a person positively interacts with other participants in psychological reality $(.282 ; p \leq .05)$ and seeks to expand their own social connections $(.322 ; p \leq .05)$, seeks to develop himself personally $(.395 ; p \leq .01)$, understanding and comprehending features of the way of life and itself $(.449 ; p \leq .01)$ the person accepts himself as he is $(.273 ; p \leq .05)$ thereby feeling internal balance $(.288 ; p \leq .05)$ and psychological well-being $(.410 ; p \leq .01)$.

Establishing correlations between indicators of a high level of psychological well-being and social expectations of student's youth gave the following results: important life goals $(.518 ; p \leq .05)$ a person sets and achieves in a clear sequence and consistency with their own ideas and expectations $(.592 ; p \leq .05)$ and enjoys the process of life $(.564 ; p \leq .05)$, feeling it to the fullest. Such a person builds positive and trusting relationships with other people $(.586 ; p \leq .05)$, expanding the field of acquaintances $(.768 ; p \leq .01)$, he is independent of social influences $(.749 ; p \leq .01)$. Strives to realize one's potential $(.620$; $p \leq .05)$, integrating one's shortcomings and advantages into life experience (.572; $p \leq .01)$. Realizing his plans, such a person effectively uses all opportunities for this $(.712 ; p \leq .01)$. Can influence the environment $(.558 ; p \leq .05)$ by expanding their social contacts $(.519$; $p \leq .05)$. Such a person is able to successfully regulate and control the events of his own life, expectations and feels mental balance and psychological well-being $(.621 ; p \leq .01)$. Such a person perceives himself as a strong, purposeful person, able to achieve the best results, accepting his experience as a value and foundation for personal development. Student's youth is characterized by an average level of psychological well-being and social expectations, which indicates a normal distribution and trend at present. It is 
determined that the level of psychological well-being corresponds to the level of social expectations, also identified the most formed components of psychological well-being: the balance of affect and meaningfulness of life. The least formed are self-acceptance, positive attitudes and autonomy.

In the scientific literature there is a large number of studies of the relationship of students' psychological well-being with different psychological phenomena: the relationship with vitality (Ma et al., 2020), personal self-realization (Chikhantsova, 2020), with personal and social identity and many others, including young people. Scientific works on the topic of social expectations (Popovych, 2017; Popovych et al., 2020a; 2021a). However, we do not find a study of the relationship between social expectations and psychological wellbeing. At present, it can be argued about the impact on the social reality of the COVID19 pandemic (Khmiliar et al., 2020). This is especially true in times of uncertainty, when psychological well-being is affected by a large number of factors, and as a result, its level decreases and thus deteriorates the state of mental health.

Psychological well-being is understood as a resource of the individual, which contributes to the successful adaptation of man to the world around him and the practical mastery of it. In this regard, research of is quite interesting, which found that predictors that positively affect the psychological well-being of students are primary and secondary abilities: fidelity, punctuality, time, hope, diligence, cleanliness (Chikhantsova, 2020).

As a person is included in society, his individual expectations are largely social, i. e. socially conditioned, which are shared with other individuals and therefore are collective (Pirozhkova, 2020). Social expectations are important as a characteristic of social consciousness and social behavior. The phenomenon of social expectations reflects the role of the subjective factor, when the individual not only influences the world around him, but also takes an active part in its construction and construction of the future (Popovych, 2021b).

Depending on the place and role of the individual in society, his self-realization, the fullness of life with meaning can be traced. The fullness of life with meaning is realized through the construction of social expectations, which are projections of its future. At the same time, the psychological semantic features of a person's social expectations are able to outline and determine his psychological well-being.

In our research, for the first time, psychological portraits of people with different levels of psychological well-being and social expectations are indicated. Student's youth with a high level of psychological well-being and social expectations is best oriented in the sociopsychological reality, is able to properly build positive relationships with other participants in social interaction, has broad social connections. They fully accept themselves as a person endowed with both positive and negative qualities and knows how to use them. Such a person is self-confident, strives for self-realization, sets far-sighted goals, and consistently achieves them. Life is perceived from the prism of positivity and well-being, joy and well-being. 
For people with an average level of psychological well-being and social expectations is characterized by objective orientation in the socio-psychological reality, based on cognitive, affective and conative components, are able to properly build their actions, predict the results of expected events. Well-developed social interaction, a person seeks to expand the circle of new acquaintances. In achieving their plans are meticulous, able to use the experience and knowledge to navigate in the surrounding space. Various things are treated with enthusiasm and curiosity. I perceive myself as a person, strives to develop and realize my potential. Perceive life in accordance with life circumstances and mood background with a predominant positive.

Student's youth with a low level of psychological well-being and social expectations, not well versed in the socio-psychological reality, difficult to integrate into it. They are not independent and dependent on the influence of others. When planning their goals have a certain sequence, but they do not have a clear idea of their implementation. Such people usually do not believe in themselves and their abilities, do not consider themselves able to overcome various difficulties in life. There are certain difficulties in social interaction, it is difficult for them to build relationships with people. They see life through the prism of incomprehensibility, dissatisfaction.

\section{Conclusions}

We summarize that the received empirical results and theoretical substantiation of psychological well-being and social expectations of the individual will contribute to the operationalization of the educational process of training and profile training; the application of research results will contribute to the construction of quality educational space in higher education institutions. Of course, it is interesting in scientific terms to study the semantic field of social expectations of university students and their impact on the components of psychological well-being.

The psychological structure and interdependence of factors of psychological well-being and social expectations of students are studied. The author's definition of the term "social expectations" is given. The psychological portrait of people with different levels of psychological well-being and social expectations is described. It was found that the respondents have an average level of parameters of psychological well-being and social expectations, which indicates moderate life satisfaction and adequate orientation in the socio-psychological reality. The most formed components of psychological well-being are the balance of affect and meaningfulness, which indicates the awareness of students' own lives, as well as the desire for its content, emotional saturation, the least formed self-acceptance, positive attitudes and autonomy. The peculiarities of the relationship between the components of psychological well-being and social expectations at low, medium and high levels are identified.

The proposed hypotheses are confirmed. The implemented theoretical and empirical complex has significant scientific facts, the application of which will promote preventive 
Oleksandr Semenov, Petro Oleshko, Svitlana Tsymbal, Vera Liashko, Alyona Shevchenko, Ihor Popovych.

and corrective and developmental work, increase the level of psychological well-being, social expectations and life satisfaction.

\section{References}

Arbeláez-Campillo, D., Tatsiy, V., Rojas-Bahamón, M., \& Danilyan, O. (2020). Contributions of critical thinking as a form of participation and political deliberation. Amazonia Investiga, 9(27), 5-12. https://doi.org/10.34069/Al/2020.27.03.1

Blynova, O., Kisil, Z., Tkach, T., Semenova, N., Semenov, O., Kamisnka, S., \& Popovych, I. (2020a). Psychological manifestations of professional marginality of future social welfare professionals. Revista Inclusiones, 7(SI), 218-233. http://www.revistainclusiones.org/index.php/inclu/article/view/1229

Blynova, O., Moiseienko, V., Los, O., Burlakova, I., Yevdokimova, O., Toba, M., \& Popovych, I. (2020b). Assertiveness as a Factor of Students' Choice of Behavior Strategies in Social Interaction. Revista Inclusiones, 7(4), 259-272. http://www.revistainclusiones.org/index.php/inclu/article/view/1551

Blynova, O., Popovych, I., Semenova, N., Kashyrina, Ye., Ursulenko, O., \& Kononenko, O. (2020c). Personality Factors of Choosing Adaptation Strategies in a Different Cultural Environment by Labor Migrants from Ukraine. Revista Amazonia Investiga, 9(32), 45-54. Retrieved from http://dx.doi.org/10.34069/Al/2020.32.08.5

Chykhantsova, O. A. (2020). A person's quality of life and features of its measurement. Insight: the psychological dimensions of society, 4, 11-28. https://doi.org/10.32999/2663-970X/2020-4-1

Griban, G., Prontenko, K., Yavorska, T., Bezpaliy, S., Bublei, T., Marushchak, M., Pustoliakova, L., Andreychuk, V., Tkachenko, P., Zhukovskyi, Ye., Baldetskiy, A., \& Bloshchynskyi, I. (2019). Non-traditional means of physical training in middle school physical education classes. International Journal of Applied Exercise Physiology, 8(3.1), 224-32. DOI: 10.26655/IJAEP.2019.10.1

Halian, I. M., Halian, O. I., Gusak, L. Ye., Bokshan, H. I., \& Popovych, I. S. (2020). Communicative Competence in Training Future Language and Literature Teachers. Revista Amazonia Investiga, 9(29), 530-541. https://amazoniainvestiga.info/index.php/amazonia/article/view/1417

Khmiliar, O., Popovych, I., Hrys, A., Pavliuk, M., Zavatska, N., Lytvynenko, O., \& Blynova, O. (2020). Spatial Regulation of Personality Behavior in the Conditions of Progression of the COVID-19 Pandemic. Revista Inclusiones, 7(SI), 289-306. http://www.revistainclusiones.org/index.php/inclu/article/view/1760

Leontyev, D. (2006). Test of life-meaningful orientations (LMO). Psychodiagnostic series. Moscow: Smysl. https://www.twirpx.com/file/83225/

Ma, F., Shevchenko, R. P., \& Karhina, N. V. (2020). Student you three presentation of psychological well-being: results of content analysis of works. Insight: the psychological dimensions of society, 3, 44-55. https://doi.org/10.32999/2663970X/2020-3-3

Neugarten, B.L., Havighurst, R.J., \& Tobin, S.S. (1961). The Measurement of Life Satis. Journal of Gerontology, 16(2), 134-143. https://doi.org/10.1093/geronj/16.2.134 
Nosov, P., Palamarchuk, I., Zinchenko, S., Popovych, I., Nahrybelnyi, Y., \& Nosova, H. (2020a). Development of means for experimental identification of navigator attention in ergatic systems of maritime transport. Bulletin of the University of Karaganda - Physics, 1(97), 58-69. https://doi.org/10.31489/2020Ph1/58-69

Nosov, P. S., Zinchenko, S. M., Popovych, I. S., Ben, A. P., Nahrybelnyi, Y. A., \& Mateichuk, V. M. (2020b). diagnostic system of perception of navigation danger when implementation complicated maneuvers. Radio Electronics, Computer Science, Control, 1, 146-161. https://doi.org/10.15588/1607-3274-2020-1-15

Pinkovetskaia, I., Arbeláez-Campillo, D., Rojas-Bahamón, M., Novikov, S., \& Veas Iniesta, D. (2020). Social values of entrepreneurship in modern countries. Amazonia Investiga, 9(28), 6-13. https://doi.org/10.34069/Al/2020.28.04.1

Pirozhkova, S. V. (2020). Social expectations: epistemic foundations and role in the knowledge society. Society. Communication. Education, 11(1), 7-18. DOI: 10.18721/JHSS.11101

Popovych, I., Arbeláez-Campillo, D. F., Rojas-Bahamón, M. J., Burlakova, I., Kobets, V., \& Bokshan, H. (2021a). Time perspective in the professional activity of specialists of economic sphere. Cuestiones Políticas, 39(69), 424-445. https://doi.org/10.46398/cuestpol.3969.27

Popovych, I., Chervinskyi, A., Kazibekova, V., Chervinska, I., \& Machynska, N. (2021b). Empirical research of the typology of social expectations of the personality. Amazonia Investiga, 10(43), 112-122. https://doi.org/10.34069/Al/2021.43.07.11

Popovych, I., Lymarenko, L., Tereshenko, N., Kornisheva, T., Yevdokimova, O., Koverznieva, A., \& Aleksieieva, M. (2020a). Research on the Effectiveness of Training Technologies' Implementation in Student Theater". Revista Inclusiones, 7(2), 104-121. http://www.revistainclusiones.org/index.php/inclu/article/view/261

Popovych, I., Shevchenko, A., Galvez, L. M., \& Klenina, K. (2021c). Research of the relationship between social desirability and value orientations of adolescents. Revista Notas Históricas y Geográficas, 26(1), 241-268. https://www.revistanotashistoricasygeograficas.cl/index.php/nhyg/article/view/339

Popovych, I. S. (2017) Psychology of social expectations of personality. (Extended abstract of Doctor's thesis). Volodymyr Dahl East-Ukrainian National University, Severodonetsk, http://ekhsuir.kspu.edu/handle/123456789/6464

Popovych, I., Blynova, O., Zhuravlova, A., Toba, M., Tkach, T., \& Zavatska, N. (2020b) Optimization of development and psycho-correction of social expectations of students of foreign philology. Revista Inclusiones, 7(SI), 82-94. http://www.revistainclusiones.org/index.php/inclu/article/view/1657

Popovych, I., Zhigarenko, I., Losiyevska, O., Dovbenko, S., Kashyrina, Ye., Shevchenko, R., \& Piletska, L. (2020c). Research of Achievement Motivation's Impaction the Career Orientations of Future Managers of Organization. Revista Inclusiones, $\quad 7(\mathrm{SI})$, 247-263. http://www.revistainclusiones.org/index.php/inclu/article/view/1231

Rojas-Bahamón, M.J., Aguilar-Cruz, P.J., \& Arbeláez-Campillo, D.F. (2020). Curricular integration as a strategy to strengthen the educational process in public institutions in COVID-19 times. Revista Inclusiones, 7 (num Especial), pp. 233-241. 
Ryff, C. (1989). Happiness is everything, or is it? Explorations on the meaning of psychological well-being. Journal of Personality and Social Psychology, 57, 1069-1081.

https://citeseerx.ist.psu.edu/viewdoc/download?doi=10.1.1.1029.4536\&rep=rep1 \&type $=p d f$

Shevchenko, A. V. (2019). research on the correlation Between social desirability and value orientations in adolescence. Insight: the psychological dimensions of society, 1, 90-95. https://doi.org/10.32999/2663-970X/2019-1-14

Shevchenko, R., Cherniavskyi, V., Zinchenko, S., Palchynska, M., Bondarevich, S., Nosov, P., \& Popovych, I. (2020). Research of psychophysiological features of response to stress situations by future sailors. Revista Inclusiones, 7(SI), 566-579. http://www.revistainclusiones.org/index.php/inclu/article/view/1780

Shiryaeva, O. S. (2008). Psychological well-being of the individual in extreme conditions of life: author. (dissertation for the degree of candidate of psychological science). Far Eastern State Transport University, Russian, 254 p. http://naukapedagogika.com/psihologiya-19-00-01/dissertaciya-psihologicheskoeblagopoluchie-lichnosti-v-ekstremalnyh-usloviyah-zhiznedeyatelnosti

Shkola, O., Griban, G., Prontenko, K., Fomenko, O., Zhamardiy, V., Bondarenko, V., Bezpaliy, S., Andreychuk, V., Tkachenko, P., Zhukovskyi, Ye., Novitska, I., \& Bloshchynskyi, I. (2019). Formation of valuable orientations in youth during physical training. International Journal of Applied Exercise Physiology, 8(3.1), 264-272. DOI: 10.26655/IJAEP.2019.10.1

Tsymbal, S. V. (2019). Enhancing students' confidence and motivation in learning English with the use of online game training sessions. Information Technologies and Learning Tools, 71(3), 227-235. https://doi.org/10.33407/itlt.v71i3.2460

Tsymbal, S. V. (2017). Overcoming language anxiety among the English language learners: psycho-pedagogical aspect. Science and Education, 7, 102-106. https://scienceandeducation.pdpu.edu.ua/en/articles/2017-7-doc/2017-7-st16-en

Villasmil Espinoza, J. J., Arbeláez-Campillo, D. F., Rojas-Bahamón, M. J. \& Parra Contreras, R. (2021) ¿Crisis del liderazgo político o liderazgo en escenarios de crisis? Revista Notas Históricas y Geográficas, 26, 269-292. https://revistanotashistoricasygeograficas.cl/carga/wpcontent/uploads/2021/04/10-Villasmil-et-al-Notas-1-2021.pdf

Zinchenko, S. M., Ben, A. P., Nosov, P. S., Popovych, I. S., Mamenko, P. P., \& Mateichuk, V. M. (2020). IMPROVING THE ACCURACY AND RELIABILITY OF AUTOMATIC VESSEL MOUTION CONTROL SYSTEM. Radio Electronics, Computer Science, Control, 2, 183-195. https://doi.org/10.15588/1607-32742020-2-19

Zinchenko, S., Nosov, P., Mateichuk, V., Mamenko, P., Popovych, I., \& Grosheva, O. (2019). Automatic collision avoidance system with many targets, including maneuvering ones. Bulletin of university of Karaganda, 96(4), 69-79. DOI: $0.31489 / 2019 \mathrm{Ph} 4 / 69-79$ 